\title{
The Effect Of Outside Corridor's Orientation to Interior Thermal Condition at Lawang Sewu Semarang.
}

\author{
Benediktus Yosef Arya Wastunimpuna ${ }^{1, *}$, Wahyu Setia Budi², and Erni Setyowati ${ }^{3}$ \\ ${ }^{1}$ Magister Program of Architecture, Department of Architecture, Faculty of Engineering, Diponegoro University, Semarang \\ ${ }^{2}$ Department of Physics, Faculty of Science and Mathematics, Diponegoro University, Semarang - Indonesia \\ ${ }^{3}$ Department of Architecture , Faculty of Engineering, Diponegoro University, Semarang - Indonesia
}

\begin{abstract}
The outside corridor of Dutch Colonial Building in Indonesia was made to make the temperature of the room more comfortable. Lawang Sewu Building in Semarang is one example of a building that has an outside corridor along the building and until now still use natural ventilation. This study focuses on finding out whether there is a difference on the thermal conditions of each room's orientation, so after that we know the effect of orientation of the outdoor corridor to the temperature of the interior. In this study the experiment based on measurement using Heat Stress WBGT Meter for Wet Bulb Temperature, Dry Bulb Temperature, Relative Humidity , and KW0600653 Hot Wire Anemometer for the air movement. The data will be analysed using thermal standard theory to find out which point has the most comfortable thermal conditions.. At the end of this study will be found the effect of corridor's orientation to thermal condition of the interior in Lawang Sewu Semarang.
\end{abstract}

Keywords: Corridor Orientation; Thermal Condition; Colonial Building; Lawang Sewu.

\section{Introduction}

Indonesia has a tropical humid climate. Therefore it has a high relative humidity content. The problem that exists in designing is how to make interior condition has a comfortable temperature. [1] In the tropical climate the biggest problem is the room temperature which can be high because the environmental temperature is indeed high. Many buildings in this climate are designed not to use natural ventilation but ultimately use Air Conditioner for their daily activities. This situation leads to wasted energy. And besides that, freon on Air Conditioner has Chloro Fluoro Carbon content which is very damaging to the earth's ozone layer. The depletion of the ozone layer causes global warming. So it should be very important to study buildings with low carbon emissions by researching buildings that still survive with natural ventilation. Actually we can learn from the Dutch colonial buildings in Indonesia. Many Dutch Colonial buildings in Indonesia are still using natural ventilation and this building is used until now.

Dutch architecture has the same characteristics as architecture in other countries that have a moderate climate in Europe. Roofs without overstek, the windows are wide and covered with glass, plain walls without sun shading are the features we can see. There is no overstek on the roof because that is not needed to protect from the sun and rain but from the snow. And there is no need to protect from the sun, because more and more are getting better for the room. The window is wide open and coated glass with the aim of still getting the sun's heat, but the wind does not enter, so the condition of the room can be warm and comfortable. [2]

There is a difference between a Dutch building in the Netherlands and a Dutch building in Indonesia. The differences include the presence of high ceilings, the existence of eaves, and the existence of outside corridors in buildings. This happens because of the adaptation of Dutch Colonial's building design to the climate of Indonesia, and this adaptation is expected to make the temperature of the room more comfortable. [3]

One of the Dutch colonial buildings that still use natural ventilation until now is Lawang Sewu Building. Established since 1907 in Semarang this building is still functional until now as Indonesian Railway museum. The building was restored in 2010 but no change at all and still the same as the original was founded. The outside corridor becomes one element of the building facade which is located along the building and has orientation to four different orientation.

Mom and Wieseborn performed research at Bandung Institute of Technology in 1939 and 1940. This research was conducted on 3 different subjects: Europeans living in Bandung, Chinese living in Bandung and Indonesians themselves. In the results obtained $19.3^{\circ} \mathrm{C}-25.1^{\circ} \mathrm{C}$ ET for the overall average sense of comfort obtained by the three subjects. In 1993 the research on thermal convenient point was also done by karyono but with the subject residing in Jakarta. The result is for operative temperature $26,7{ }^{\circ} \mathrm{C}$ and for equivalent temperature $25,3{ }^{\circ} \mathrm{C}$. [4] L.M.F

* Corresponding author: josepharyawastu@gmail.com 
Purwanto (2004) said that there are three thermal comfort standards. The three thermal comfort standards are : (a) $20.5^{\circ} \mathrm{C}-24.5^{\circ} \mathrm{C}$ effective temperature (b) Relative humidity at $40 \%-70 \%$, and (c) Air movement 0.1-1.5 m / s. [2]

In this study focuses on finding whether there are differences in thermal conditions that occur due to the difference in the position of the Lawang Sewu's outside corridor The method in this research is by doing the measurement directly to the site. The data will be analysed by using thermal standard theory and Olygay diagram to find out which point has the most comfortable thermal conditions. This research will be useful when an architect will choose the location of an effective corridor orientation. By choosing an effective corridor location, it will help us to make the room more thermally comfortable without air conditioner. The less use of air conditioning has an impact on carbon emissions that will be lower.

\section{Methods}

\subsection{Description of Selected Rooms and Measuring Point}

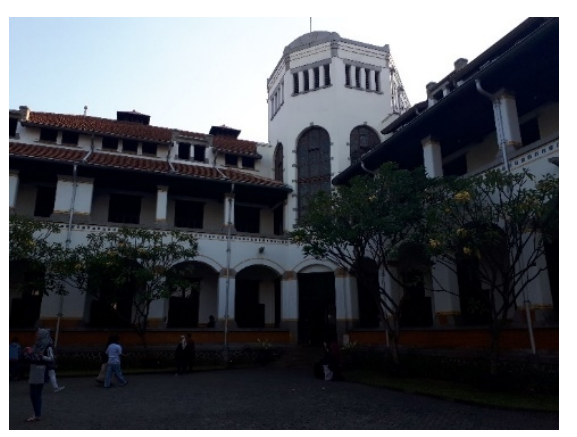

Fig. 1. The A Building of Lawang Sewu

The A building was chosen because only this building has an outside corridor with four different orientations so we can know the thermal conditions of each orientation space. From each orientation will be taken one outside corridor and one room to be measured. And the measurement will be done on two floors. The orientation found in this research measurement is southeast, southwest, northeast, and northwest.

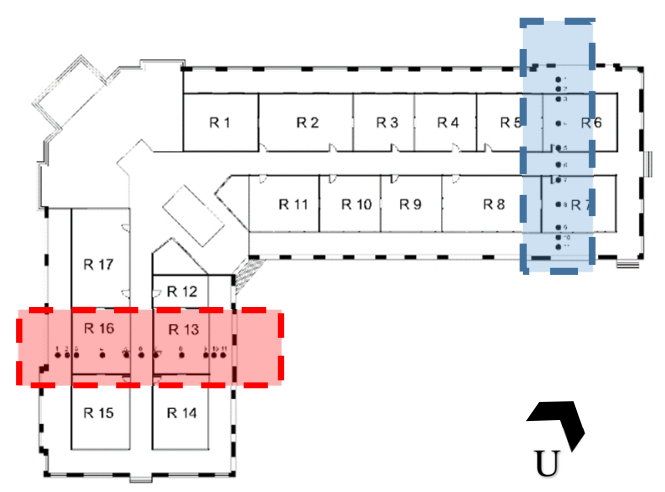

Fig. 2. Measure Point of $1^{\text {st }}$ floor from the A building

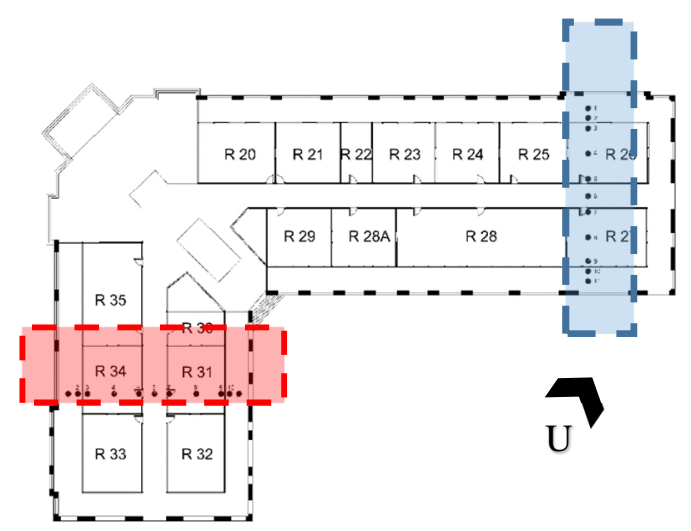

Fig. 3. Measure Point of $2^{\text {nd }}$ floor from the A building

The room that will be measured on the $1^{\text {st }}$ floor is:

1. Outside Corridor from R 6 ( Northwest Orientation)

2. R 6 ( Northwest Orientation)

3. Central Corridor ( Northwest and Southeast Orientation)

4. R 7 ( Southeast Orientation )

5. Outside Corridor from R 7 ( Southeast Orientation )

6. Outside Corridor from R 16 ( Southwest Orientation )

7. R 16 ( Southwest Orientation )

8. Central Corridor ( Southwest and Northeast Orientation)

9. R 13 ( Northeast Orientation)

10. Outside Corridorr from R 13 ( Northeast Orientation)

The room that will be measured on the $2^{\text {nd }}$ floor is::

1. Outside Corridor from R 26 ( Northwest Orientation)

2. R 26 ( Northwest Orientation)

3. Central Corridor ( Northwest and Southeast Orientation)

4. R 27 ( Southeast Orientation )

5. Outside Corridor from R 27 ( Southeast Orientation )

6. Outside Corridor from R 34 ( Southwest Orientation )

7. R 34 ( Southwest Orientation )

8. Central Corridor ( Southwest and Northeast Orientation)

9. R 31 ( Northeast Orientation )

10. Outside Corridor from R 31 ( Northeast Orientation)

\subsection{The Measurement Steps}

After determining the measuring point, the next step is to make a measurement at a specified point with a heat stress WBGT meter, Hot Wired Anemometer, and Lux Meter. Heat Stress WBGT meter for measure wet bulb temperature, dry bulb temperature and relative humidity. Hot Wired Anemometer to measure air movement and Luxmeter for measure the intensity of the light. 

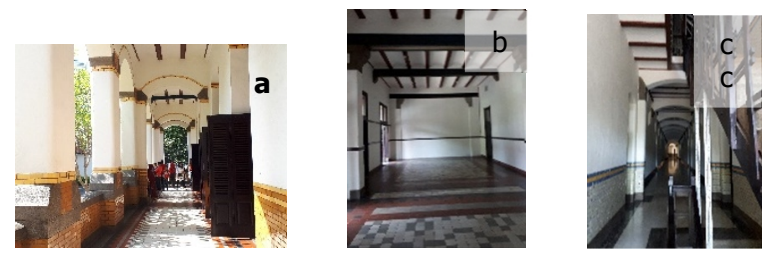

Fig. 4. The Corridor ( a) the room behind the corridor (b) central corridor / The Hall (c)

Measurements were performed in each room orientation, with measurement points located at:

1. Corridor

2. A point outside the door bordering the corridor

3. A point inside the door bordering the corridor

4. Room interior

5. A point inside the door bordering the central corridor

6. Central corridor

Measurements are performed using the tools mentioned above. Lawang Sewu now serves as a railway museum of Indonesia. Therefore the existing activity is looking at historic items. This situation makes the measuring point is at 1 meter above the ground. Each measurement is repeated three times, and and performed throughout the day from opening hours until closing hours ( 8 a.m.to 7 p.m )

\subsection{Description of How to Analyse The Data}

From the measurement result will get Wet Bulb Temperature (WBT) , Dry Bulb Temperature (DBT), Relative Humidity, Air movement, and light intensity. For WBT, DBT, and air movement we will input into the effective temperature diagram, to get the effective temperature.

After obtaining effective temperature, relative humidity, and air movement, we analyse the three data using existing thermal comfort standard theory. Theory to analyze using theory from Purwanto, Mom and Wieseborn,

\section{Results and Discussion}

\subsection{The Effective Temperature of each measurement point}

Table 1. Effective Temperature of Northwest Orientation at the $1^{\text {st }}$ floor

\begin{tabular}{|c|c|c|c|}
\hline $\begin{array}{c}\text { Measurement } \\
\text { Point }\end{array}$ & 8 a.m $\left({ }^{0} \mathrm{C}\right)$ & 1 p.m $\left({ }^{0} \mathrm{C}\right)$ & $5 \mathrm{p} . \mathrm{m}\left({ }^{\circ} \mathrm{C}\right)$ \\
\hline $\begin{array}{c}\text { Outside } \\
\text { Corridor }\end{array}$ & 28 & 28 & 27.5 \\
\hline R 6 & 27 & 28 & 27 \\
\hline Hall & 27.5 & 27 & 27 \\
\hline
\end{tabular}

Table 2. Effective Temperature of Southeast Orientation at the $1^{\text {st }}$ floor

\begin{tabular}{|c|c|c|c|}
\hline $\begin{array}{c}\text { Measurement } \\
\text { Point }\end{array}$ & 8 a.m $\left({ }^{0} \mathrm{C}\right)$ & 1 p.m $\left({ }^{0} \mathrm{C}\right)$ & 5 p.m $\left({ }^{0} \mathrm{C}\right)$ \\
\hline $\begin{array}{c}\text { Outside } \\
\text { Corridor }\end{array}$ & 27 & 27 & 27 \\
\hline R 7 & 26.5 & 28 & 27.5 \\
\hline Hall & 27 & 27 & 27.5 \\
\hline
\end{tabular}

Table 3. Effective Temperature of Southwest Orientation at the $1^{\text {st }}$ floor

\begin{tabular}{|c|c|c|c|}
\hline $\begin{array}{c}\text { Measurement } \\
\text { Point }\end{array}$ & 8 a.m $\left({ }^{0} \mathrm{C}\right)$ & 1 p.m $\left({ }^{0} \mathrm{C}\right)$ & 5 p.m $\left({ }^{0} \mathrm{C}\right)$ \\
\hline $\begin{array}{c}\text { Outside } \\
\text { Corridor }\end{array}$ & 26 & 29 & 27 \\
\hline R 16 & 26.5 & 28.5 & 28 \\
\hline Hall & 25.5 & 28 & 27 \\
\hline
\end{tabular}

Table 4. Effective Temperature of Northeast Orientation at the $1^{\text {st }}$ floor

\begin{tabular}{|c|c|c|c|}
\hline $\begin{array}{c}\text { Measurement } \\
\text { Point }\end{array}$ & 8 a.m $\left({ }^{0} \mathrm{C}\right)$ & 1 p.m $\left({ }^{0} \mathrm{C}\right)$ & $5 \mathrm{p} . \mathrm{m}\left({ }^{0} \mathrm{C}\right)$ \\
\hline $\begin{array}{c}\text { Outside } \\
\text { Corridor }\end{array}$ & 26.5 & 28 & 27 \\
\hline R 13 & 26.5 & 28 & 28 \\
\hline Hall & 25.5 & 28.5 & 27 \\
\hline
\end{tabular}

Table 5. Effective Temperature of Northwest Orientation at the $2^{\text {nd }}$ floor

\begin{tabular}{|c|c|c|c|}
\hline $\begin{array}{c}\text { Measurement } \\
\text { Point }\end{array}$ & 8 a.m $\left({ }^{0} \mathrm{C}\right)$ & 1 p.m $\left({ }^{0} \mathrm{C}\right)$ & 5 p.m $\left({ }^{0} \mathrm{C}\right)$ \\
\hline $\begin{array}{c}\text { Outside } \\
\text { Corridor }\end{array}$ & 25.5 & 25.5 & 26 \\
\hline R 26 & 26 & 26.5 & 27.5 \\
\hline Hall & 26.5 & 25 & 27 \\
\hline
\end{tabular}

Table 6. Effective Temperature of Southeast Orientation at the $2^{\text {nd }}$ floor

\begin{tabular}{|c|c|c|c|}
\hline $\begin{array}{c}\text { Measurement } \\
\text { Point }\end{array}$ & 8 a.m $\left({ }^{0} \mathrm{C}\right)$ & 1 p.m $\left({ }^{0} \mathrm{C}\right)$ & 5 p.m $\left({ }^{0} \mathrm{C}\right)$ \\
\hline $\begin{array}{c}\text { Outside } \\
\text { Corridor }\end{array}$ & 25.5 & 25 & 27 \\
\hline R 27 & 25.5 & 26 & 27 \\
\hline Hall & 26 & 25 & 27 \\
\hline
\end{tabular}

Table 7. Effective Temperature of Southwest Orientation at the $2^{\text {nd }}$ floor

\begin{tabular}{|c|c|c|c|}
\hline $\begin{array}{c}\text { Measurement } \\
\text { Point }\end{array}$ & 8 a.m $\left({ }^{0} \mathrm{C}\right)$ & 1 p.m $\left({ }^{\circ} \mathrm{C}\right)$ & 5 p.m $\left({ }^{\circ} \mathrm{C}\right)$ \\
\hline
\end{tabular}




\begin{tabular}{|c|c|c|c|}
\hline $\begin{array}{c}\text { Outside } \\
\text { Corridor }\end{array}$ & 27 & 25 & 26 \\
\hline R 34 & 26 & 26.5 & 27 \\
\hline Hall & 25 & 25 & 27 \\
\hline
\end{tabular}

Table 8. Effective Temperature of Northeast Orientation at the $2^{\text {nd }}$ floor

\begin{tabular}{|c|c|c|c|}
\hline $\begin{array}{c}\text { Measurement } \\
\text { Point }\end{array}$ & 8 a.m $\left({ }^{0} \mathrm{C}\right)$ & $1 \mathrm{p} . \mathrm{m}\left({ }^{0} \mathrm{C}\right)$ & $5 \mathrm{p} . \mathrm{m}\left({ }^{0} \mathrm{C}\right)$ \\
\hline $\begin{array}{c}\text { Outside } \\
\text { Corridor }\end{array}$ & 26.5 & 26 & 26.5 \\
\hline R 31 & 26 & 26.5 & 27 \\
\hline Hall & 25 & 24.5 & 27 \\
\hline
\end{tabular}

\subsection{The Relative Humidity of each measurement point}

Table 9. Relative Humidity of Northwest Orientation at the $1^{\text {st }}$ floor

\begin{tabular}{|c|c|c|c|}
\hline $\begin{array}{c}\text { Measurement } \\
\text { Point }\end{array}$ & 8 a.m & 1 p.m & 5 p.m \\
\hline $\begin{array}{c}\text { Outside } \\
\text { Corridor }\end{array}$ & 67.6 & 59 & $(\%)$ \\
\hline R 7 & 67.3 & 60 & 65.7 \\
\hline Hall & 69.9 & 60.5 & 65.9 \\
\hline
\end{tabular}

Table 10. Relative Humidity of Southeast Orientation at the $1^{\text {st }}$ floor

\begin{tabular}{|c|c|c|c|}
\hline $\begin{array}{c}\text { Measurement } \\
\text { Point }\end{array}$ & 8 a.m. & 1 p.m. & 5 p.m. \\
\hline $\begin{array}{c}\text { Outside } \\
\text { Corridor }\end{array}$ & 66.6 & 58.1 & $(\%)$ \\
\hline R 6 & 68.3 & 57.7 & 64.3 \\
\hline Hall & 69.9 & 60.5 & 65.6 \\
\hline
\end{tabular}

Table 11. Relative Humidity of Southwest Orientation at the $1^{\text {st }}$ floor

\begin{tabular}{|c|c|c|c|}
\hline $\begin{array}{c}\text { Measurement } \\
\text { Point }\end{array}$ & 8 a.m & 1 p.m & 5 p.m \\
\hline $\begin{array}{c}\text { Outside } \\
\text { Corridor }\end{array}$ & 75.9 & 56.2 & $(\%)$ \\
\hline R 16 & 74.2 & 56.2 & 63.2 \\
\hline Hall & 70.6 & 55.2 & 63.2 \\
\hline
\end{tabular}

Table 12. Relative Humidity of Northeast Orientation at the $1^{\text {st }}$ floor

\begin{tabular}{|c|c|c|c|}
\hline $\begin{array}{c}\text { Measurement } \\
\text { Point }\end{array}$ & 8 a.m & 1 p.m & 5 p.m \\
\hline $\begin{array}{c}\text { Outside } \\
\text { Corridor }\end{array}$ & 67.6 & 56.7 & $(\%)$ \\
\hline R 13 & 72.2 & 55.5 & 64 \\
\hline Hall & 70.6 & 55.2 & 64 \\
\hline
\end{tabular}

Table 13. Relative Humidity of Northwest Orientation at the $2^{\text {nd }}$ floor

\begin{tabular}{|c|c|c|c|}
\hline $\begin{array}{c}\text { Measurement } \\
\text { Point }\end{array}$ & 8 a.m & 1 p.m & 5 p.m \\
\hline $\begin{array}{c}\text { Outside } \\
\text { Corridor }\end{array}$ & 62.5 & 51.2 & $(\%)$ \\
\hline R 26 & 61.2 & 52 & 65.7 \\
\hline Hall & 62.5 & 51.1 & 65.2 \\
\hline
\end{tabular}

Table 14. Relative Humidity of Southeast Orientation at the $2^{\text {nd }}$ floor

\begin{tabular}{|c|c|c|c|}
\hline $\begin{array}{c}\text { Measurement } \\
\text { Point }\end{array}$ & 8 a.m & 1 p.m & 5 p.m \\
\hline $\begin{array}{c}\text { Outside } \\
\text { Corridor }\end{array}$ & 60.2 & 50.2 & $(\%)$ \\
\hline R 27 & 61.1 & 52.1 & 67.7 \\
\hline Hall & 62.5 & 51.1 & 65.8 \\
\hline
\end{tabular}

Table 15. Relative Humidty of Southwest Orientation at the $2^{\text {nd }}$ floor

\begin{tabular}{|c|c|c|c|}
\hline $\begin{array}{c}\text { Measurement } \\
\text { Point }\end{array}$ & 8 a.m & 1 p.m & 5 p.m \\
\hline $\begin{array}{c}\text { Outside } \\
\text { Corridor }\end{array}$ & 60.5 & 55.9 & 60.2 \\
\hline R 34 & 62.9 & 54.8 & 67.3 \\
\hline Hall & 63.3 & 55.6 & 66.7 \\
\hline
\end{tabular}

Table 16. Relative of Northeast Orientation at the $2^{\text {nd }}$ floor

\begin{tabular}{|c|c|c|c|}
\hline $\begin{array}{c}\text { Measurement } \\
\text { Point }\end{array}$ & 8 a.m. & 1 p.m. & 5 p.m. \\
\hline $\begin{array}{c}\text { Outside } \\
\text { Corridor }\end{array}$ & 63.2 & 58.6 & $(\%)$ \\
\hline R 31 & 64.1 & 55 & 67.5 \\
\hline Hall & 63.3 & 55.6 & 66.3 \\
\hline
\end{tabular}

\subsection{Analysis of measurement data}

\subsubsection{With Purwanto Theory}

Table 17. Thermal Condition at 8 a.m.

\begin{tabular}{|l|l|l|l|l|}
\hline \multirow{2}{*}{ ORIENTATION } & \multicolumn{3}{|l|}{$1^{\text {st }}$ FLOOR } & $2^{\text {nd }}$ FLOOR \\
\cline { 2 - 5 } & $\begin{array}{l}\text { ET } \\
\left({ }^{\circ} \mathrm{C}\right)\end{array}$ & RH $(\%)$ & ET $\left({ }^{\circ} \mathrm{C}\right)$ & RH $(\%)$ \\
\cline { 2 - 5 } & $20-24.5$ & $40-70$ & $20-24.5$ & $40-70$ \\
\hline Northwest & 27 & 67.3 & 26 & 61.2 \\
\hline Southeast & 26.5 & 68.3 & 25.5 & 61.1 \\
\hline Southwest & 26.5 & 74.2 & 26 & 62.9 \\
\hline Northeast & 26.5 & 72.2 & 26 & 64.1 \\
\hline
\end{tabular}

At 8 am, the measurements show that for southwest and northeast orientations, it is more uncomfortable than northwest and southeast orientations at the $1^{\text {st }}$ floor. And for the $2^{\text {nd }}$ floor, southeast orientation is the most comfortable. 
Table 18. Thermal Condition at 1 p.m.

\begin{tabular}{|l|l|l|l|l|}
\hline \multirow{2}{*}{ ORIENTATION } & \multicolumn{2}{|l|}{$1^{\text {st }}$ FLOOR } & \multicolumn{2}{|l|}{$2^{\text {nd }}$ FLOOR } \\
\cline { 2 - 5 } & $\begin{array}{l}\text { ET } \\
\left({ }^{0} \mathrm{C}\right)\end{array}$ & RH $(\%)$ & ET $\left({ }^{0} \mathrm{C}\right)$ & RH $(\%)$ \\
\cline { 2 - 5 } & $20-24.5$ & $40-70$ & $20-24.5$ & $40-70$ \\
\hline Northwest & 28 & 60 & 26.5 & 52 \\
\hline Southeast & 28.5 & 57.7 & 26 & 52.1 \\
\hline Southwest & 28 & 56.2 & 26.5 & 54.8 \\
\hline Northeast & 28 & 55.5 & 26.5 & 55 \\
\hline
\end{tabular}

At 1 p.m, the measurements show that northeast orientation is the most comfortable at $1^{\text {st }}$ floor. And for the $2^{\text {nd }}$ floor, southeast orientation is the most comfortable.

Table 19. Thermal Condition at 5 p.m.

\begin{tabular}{|l|l|l|l|l|}
\hline \multirow{2}{*}{ ORIENTATION } & \multicolumn{3}{|l|}{$1^{\text {st }}$ FLOOR } & \multicolumn{2}{l|}{$2^{\text {nd }}$ FLOOR } \\
\cline { 2 - 5 } & $\begin{array}{l}\text { ET } \\
\left({ }^{0} \mathrm{C}\right)\end{array}$ & RH $(\%)$ & ET $\left({ }^{0} \mathrm{C}\right)$ & RH $(\%)$ \\
\cline { 2 - 5 } & $20-24.5$ & $40-70$ & $20-24.5$ & $40-70$ \\
\hline Northwest & 27 & 65.9 & 27.5 & 65.2 \\
\hline Southeast & 27.5 & 65 & 27 & 65.7 \\
\hline Southwest & 28 & 65.7 & 27 & 67.3 \\
\hline Northeast & 28 & 67.7 & 27 & 66.3 \\
\hline
\end{tabular}

At 5 p.m. , the measurement show that Northwest orientation is the most comfortable at $1^{\text {st }}$ floor. And for the $2^{\text {nd }}$ floor, Souteast orientation is the most comfortable.

So with this analysis, we can conclude that a room with an outside corridor, which has an orientation to northeast and southeast is the most comfortable.

\subsubsection{With Mom and Wieseborn Theory}

Table 20. Thermal Condition at 8 a.m.

\begin{tabular}{|l|l|l|}
\hline \multirow{2}{*}{ ORIENTATION } & $1^{\text {st }}$ FLOOR & $2^{\text {nd }}$ FLOOR \\
\cline { 2 - 3 } & $\mathrm{ET}\left({ }^{0} \mathrm{C}\right)$ & $\mathrm{ET}\left({ }^{0} \mathrm{C}\right)$ \\
\cline { 2 - 3 } & $19.3-25.1$ & $19.3-25.1$ \\
\hline Northwest & 27 & 26 \\
\hline Southeast & 26.5 & 25.5 \\
\hline Southwest & 26.5 & 26 \\
\hline Northeast & 26.5 & 26 \\
\hline
\end{tabular}

At 8 am, the measurements show that for southwest, southeastt and northeast orientations, it is more uncomfortable than northwest at the $1^{\text {st }}$ floor. And for the $2^{\text {nd }}$ floor, southeast orientation is the most comfortable.

Table 21. Thermal Condition at 1 p.m.

\begin{tabular}{|l|l|l|}
\hline \multirow{2}{*}{ ORIENTATION } & $1^{\text {st }}$ FLOOR & $2^{\text {nd }}$ FLOOR \\
\cline { 2 - 3 } & $\mathrm{ET}\left({ }^{0} \mathrm{C}\right)$ & $\mathrm{ET}\left({ }^{0} \mathrm{C}\right)$ \\
\cline { 2 - 3 } & $19.3-25.1$ & $19.3-25.1$ \\
\hline Northwest & 28 & 26.5 \\
\hline Southeast & 28.5 & 26 \\
\hline Southwest & 28 & 26.5 \\
\hline Northeast & 28 & 26.5 \\
\hline
\end{tabular}

At 1p.m., the measurements show that for southwest, northwest and northeast orientations, it is more uncomfortable than northwest at the $1^{\text {st }}$ floor. And for the $2^{\text {nd }}$ floor, southeast orientation is the most comfortable.
Table 22. Thermal Condition at 5 p.m.

\begin{tabular}{|l|l|l|}
\hline \multirow{3}{*}{ ORIENTATION } & $1^{\text {st }}$ FLOOR & $2^{\text {nd }}$ FLOOR \\
\cline { 2 - 3 } & $\mathrm{ET}\left({ }^{0} \mathrm{C}\right)$ & $\mathrm{ET}\left({ }^{0} \mathrm{C}\right)$ \\
\cline { 2 - 3 } & $19.3-25.1$ & $19.3-25.1$ \\
\hline Northwest & 27 & 27.5 \\
\hline Southeast & 27.5 & 27 \\
\hline Southwest & 28 & 27 \\
\hline Northeast & 28 & 27 \\
\hline
\end{tabular}

At 5 p.m., the measurements show that northwest is the most comfortable at . And for the $2^{\text {nd }}$ floor, southeast orientation is the most comfortable. And for the $2^{\text {nd }}$ floor, southeast, southwest and northeast orientation more comfortable than northwest orientation.

\section{Conclusion}

The existence of the outside corridor at Lawang Sewu was indeed have an influence on the thermal conditions of the room. It is seen from the thermal conditions that still survive at a comfortable point, though lawang sewu just rely on natural ventilation from the beginning until now. It is not in a very comfortable position, but with the age of the building is 100 years old and still survive quite comfortably it is very nice. After analysing the existing theory (Purwanto and Mom and Wieseborn, ), the orientation of the building to the southeast, has the most thermally comfortable room. Though the temperature in the corridor is quite high, but it turns out the function of the corridor to be a circular space for hot and cold air changes succeed. so that the temperature inside the room becomes more comfortable.

This study proves that the existence of outside corridors can be a solution for buildings with large masses but still can maximize natural ventilation. And this study has proved that the outside corridor can be a hot and cold air change room, so the room becomes more comfortable and we can also find the most effective direction in laying corridors. Because with using maximum natural ventilation in buildings will minimize energy consumption. This will have a very good impact for the future. Because in addition to saving energy, minimizing the use of air conditioning can reduce the latent effects of carbon emissions that can damage the ozone layer on the earth..

\section{References}

[1] N. C. Idham, Arsitektur dan Kenyamanan Termal. Yogyakarta: Penerbit Andi, 2015.

[2] L.M.F. Purwanto, "Kenyamanan Termal Pada Bangunan Kolonial Belanda Di Semarang," Dimensi. Jurnal Tek. Arsitektur, vol. 32, no. 2, pp. 138-149, 2004.

[3] A. Ardiyanto, "Strategi Arsitektural Dalam Penentuan Kinerja Termal Paoa Bangunan Kantor Kolonial Semarang," 2015.

[4] T. H. Karyono, "Thermal Comfort in the Tropical South East Asia Region," Archit. Sci. Rev., vol. 39, no. 3, pp. 135-139, 1996. 